\title{
Educational research on solving real tax problems in cross- border e-commerce
}

\section{Investigación educativa sobre la resolución de problemas fiscales reales en el comercio electrónico transfronterizo}

\author{
Svetlana Vitalievna Salmina* \\ Senior Lecturer, Department of Economic Security and Taxation, Institute of Management, \\ Economics and Finance, Kazan Federal University \\ http://orcid.org/0000-0002-1897-0975 \\ Elmira Kamilevna Khafizova \\ Assistant Lecturer, Department of Economic Security and Taxation, Institute of Management, \\ Economics and Finance, Kazan Federal University \\ http://orcid.org/0000-0002-8117-9190 \\ Yulia Nikolaevna Balabanova \\ Senior Lecturer, Department of Economic Security and Taxation, Institute of Management, \\ Economics and Finance, Kazan Federal University \\ http://orcid.org/0000-0001-8960-0739
}

Received 09-08-20 Revised 10-10-20

Accepted 20-12-21 On line 03-17-21

* Correspondence

Email: svetasv21@yandex.ru 


\section{Summary}

The paper considers current taxation problems in cross-border electronic commerce in goods, the share of which in total trade continues to grow. Considering the field of economics as a part of university education, which can play a prominent role in solving the current problems, we suggests possible ways of regulating the cross-border e-commerce taxation by involving digital platforms in the taxation process and making them fully or partially liable for tax obligations. In addition, the establishment of university educational courses in the field of economics has been proposed as a way to improve the economic situation

Keywords: e-commerce, Educational system, cross-border e-commerce, taxation, digital platform, VAT

\section{Resumen}

El documento considera los problemas fiscales actuales en el comercio electrónico transfronterizo de mercancías, cuya participación en el comercio total sigue creciendo. Considerando el campo de la economía como parte de la formación universitaria, que puede jugar un papel destacado en la solución de los problemas actuales, sugerimos posibles formas de regular la tributación del comercio electrónico transfronterizo involucrando plataformas digitales en el proceso tributario y haciéndolas plenamente o parcialmente responsable de las obligaciones fiscales. Además, se ha propuesto el establecimiento de cursos de formación universitaria en el campo de la economía como una forma de mejorar la situación económica.

Palabras clave: comercio electrónico, sistema educativo, comercio electrónico transfronterizo, impuestos, plataforma digital, IV

\section{Introduction}

Online e-commerce, which is gaining in its popularity in the Internet network, is growing annually; global rate of sales of goods through e-commerce totals US \$2 trillion in 2019. This figure is expected to double by 2021 , reaching US $\$ 4.5$ trillion. The situation in the Russian e-commerce market shows a similar trend.

\section{Methods}

Analysing the dynamics of e-commerce turnover trend, the Association of Internet Commerce Companies (AICC) notes that its volume increased by 30\% in 2019 compared to 2018 (https://www.akit.ru). 


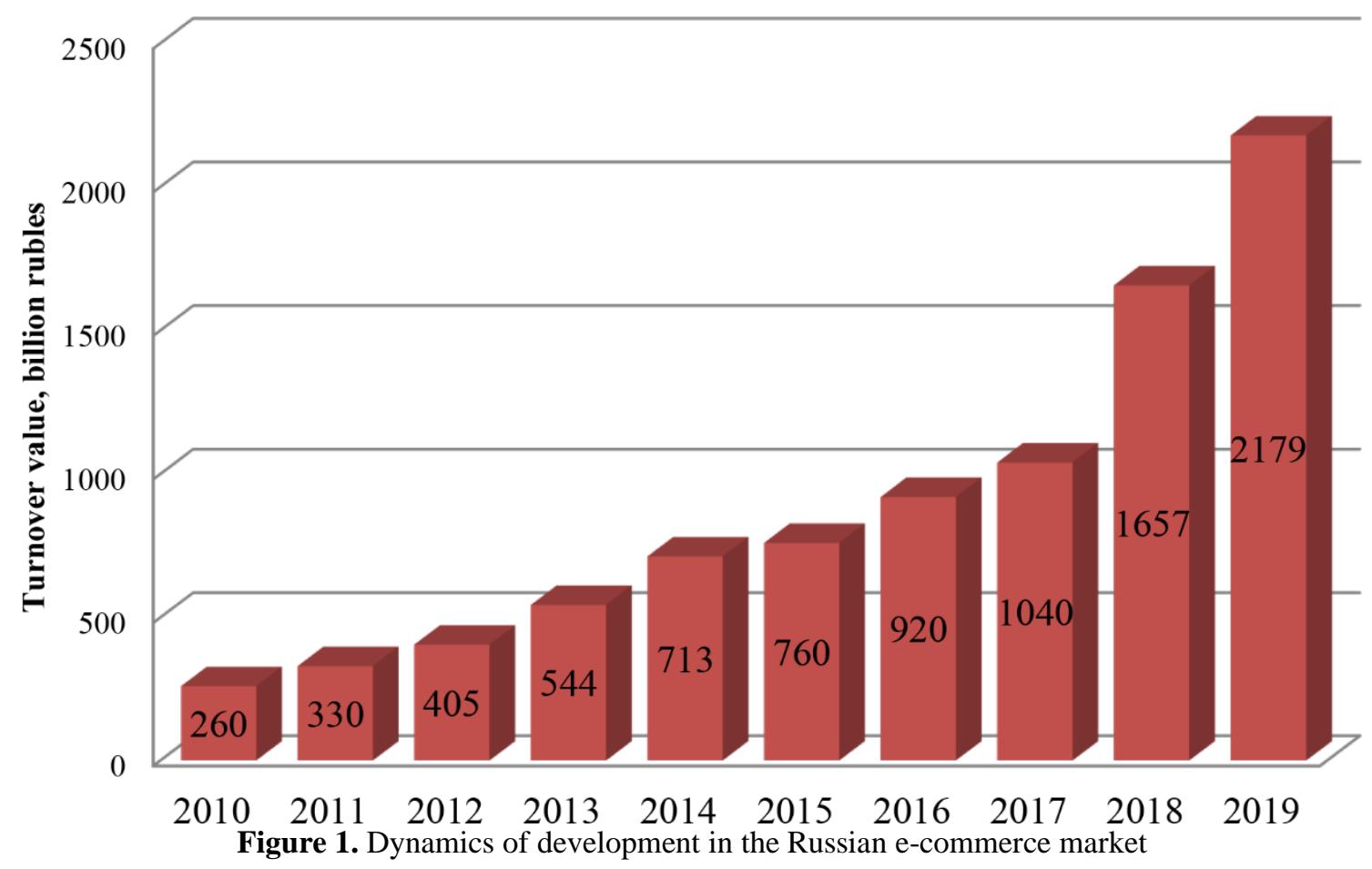

As Figure 1 shows, cross-border e-commerce is rapidly gaining momentum not only globally but also in Russia. The main factor behind the growth of cross-border trade in the Russian e-commerce market is the increase in the number of foreign suppliers offering their goods in the Russian Federation. The number of goods moved in international postal items is increasing exponentially. The Russian Post is increasing its delivery share in the e-commerce market every year and accounts for about $20 \%$ of the entire Russian digital economy (Figure 2).

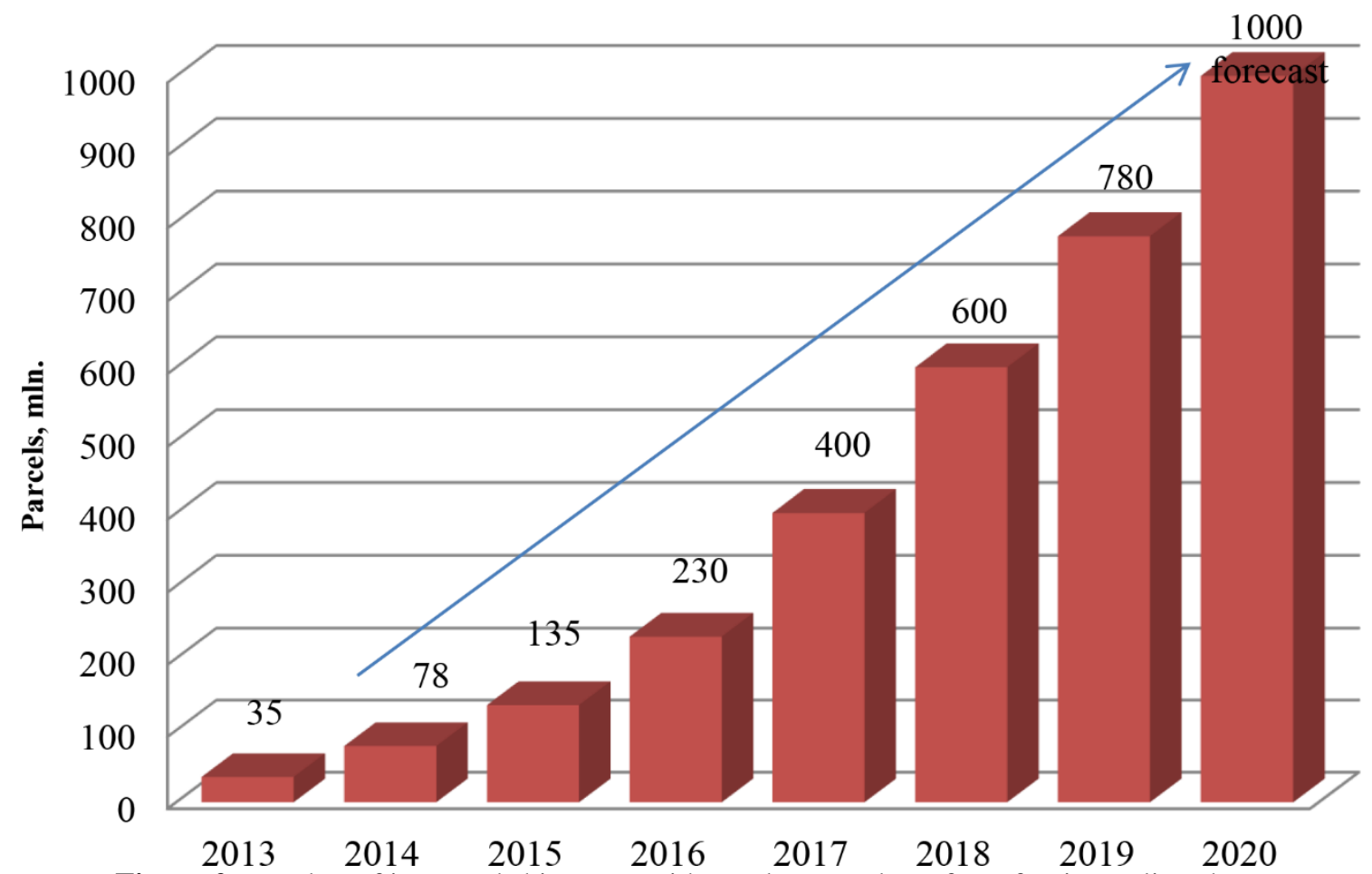

Figure 2. Number of imported shipments with goods or products from foreign online shops (https://www.interfax.ru).

However, the growth of the foreign market among Russian buyers leads to unequal conditions in the conduct of business between Russian and foreign suppliers. This inequality is caused by the existence of different business practices. For example, Russian online sellers are obliged to comply with all tax legislation requirements, from registration with the tax authorities to 
payment of all statutory taxes, levies and duties. Foreign suppliers, on the other hand, benefit from duty-free importation of goods into Russia; they do not have to both register with the Russian tax authorities and pay any fees. This exemption is established by Decision No. 107 of the Council of the Eurasian Economic Commission dated 20 December 2017 (hereinafter, the CECC Decision). The rules established by the CECC Decision exempt foreign sellers from taxation of goods imported into the customs territory of the CECC; this means the imported goods which value does not exceed the equivalent of 200 euro per individual. As statistics show, Russian buyers most often buy goods in foreign online shops with a value not exceeding EUR 22. Thus, most foreign suppliers fall within the duty-free threshold (selling "low-value" goods) and thus reduce their fiscal burden. As Table 1 shows, the difference in business margins is $30 \%$ (http://base.garant.ru).

Table 1. Formation of unequal conditions for doing business on the Internet (Tax Code (Part I) of the Russian Federation of July 31, 1998; Tax Code (Part II) of August 5, No. 117 - FZ)

\begin{tabular}{|c|c|c|c|}
\hline \multicolumn{2}{|c|}{$\begin{array}{l}\text { Sale of Russian or imported goods on the } \\
\text { territory of the Russian Federation }\end{array}$} & \multicolumn{2}{|c|}{$\begin{array}{l}\text { Sale of foreign goods directly to a buyer in the } \\
\text { Russian Federation }\end{array}$} \\
\hline VAT & $20 \%$ & VAT & $0 \%$ \\
\hline Duty (average) & $8 \%$ & Duty & $0 \%$ \\
\hline Service and warranty & \multirow{6}{*}{$4 \%$} & \multirow{6}{*}{$\begin{array}{l}\text { No importer, service and warranty } \\
\text { maintenance, certification, etc. are } \\
\text { required. }\end{array}$} & \multirow[t]{6}{*}{$0 \%$} \\
\hline Official importer & & & \\
\hline Russian information, marking & & & \\
\hline Certification & & & \\
\hline Consumer rights Protection & & & \\
\hline Fiscalization & & & \\
\hline Total & $30 \%$ & Total & $0 \%$ \\
\hline
\end{tabular}

Due to the fact that cross-border trade is effectively unencumbered by the fiscal burden, the volume of non-taxable trade has increased 14.5 -fold over the last six years, amounting to RUB 316 billion in 2018, with the market share of local online retailers declining from $92 \%$ to $67 \%$ over the same period and, in contrast, the share of cross-border trade rising from $8 \%$ to $33 \%$ in 2016.

\section{Results and Discussion}

According to AICC forecasts, cross-border trade will account for $51 \%$ of the market in 2020, with local retailers accounting for 49\% (Figure 3) (https://www.akit.ru).

2010

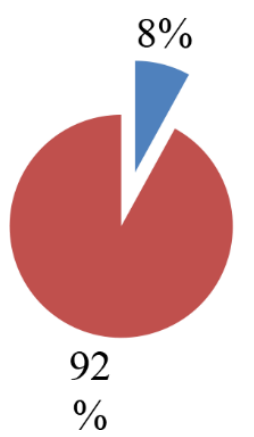

2015

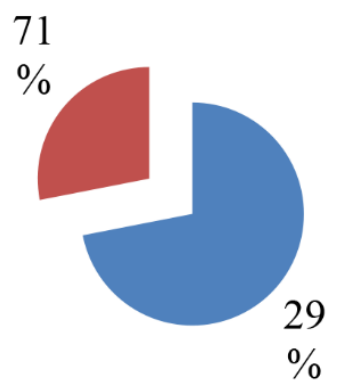

2016

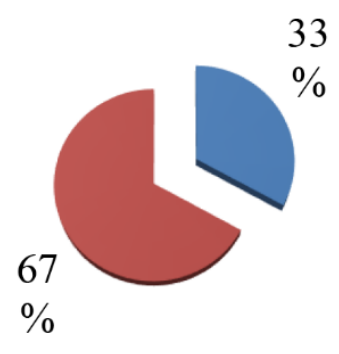

2020 forecast

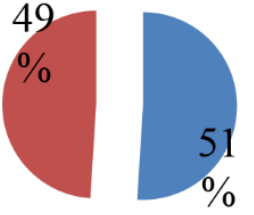

Figure 3. Prospects for the e-commerce development in Russia

In our view, such dynamics is related to the lack of balanced regulation in this area and creates unfavourable competitive conditions for local retailers in cross-border e-commerce. It is worth noting that at the international level, the Organisation for Economic Cooperation and Development (OECD) plays a key role in preventing and countering abusive tax competition. Against the enormous growth in online commerce, the OECD points to the need to increase VAT collection in a cross-border trade environment. In its report "The Role of Digital Platforms in Generating VAT from Online Sales", the OECD looks at a possible solution to countries' revenue shortfall, also the unfair distribution of the tax burden between local and foreign sellers of goods in 
cross-border e-commerce. The OECD solution relates to the imposition of VAT on sales performed by foreign sellers, and VAT should be collected by the tax authorities of the jurisdictions in which the purchasers of the goods are residents (http://base.garant.ru; Zaponkina, 2020; www.oecd.org).

According to the OECD, digital platforms play a crucial role in the facilitation and implementation of e-commerce by providing a direct interface between trading parties. As part of its report, the OECD proposes the involvement of digital platforms in fulfilling tax obligations to calculate, withhold, and pay taxes instead of the main suppliers of goods. It is important to note that the report provides 3 main options for the involvement of digital platforms in the collection of VAT on the sale of goods through e-commerce (http://base.garant.ru).

1. Full (sole) liability regime. The digital platform has a full obligation to calculate, withhold, and pay VAT in connection with its online sales within the tax jurisdiction territory. The essence of this regime is that the seller delivers goods with a value below the customs threshold through the platform to the buyer located in the jurisdiction. The platform through which the sale is made is fully liable for VAT on the online sale. It is important to note that the main supplier retains the right to receive a deduction for "input" VAT in accordance with the normal rules (Adigamova Farida et al., 2014). The buyer has the right to settle the purchase with both the platform and the main supplier. In case the payment is made to the platform, the platform remits the VAT to the relevant tax authority of the jurisdiction; in case the payment is made to the supplier, the platform must receive the VAT from the supplier in order to meet its tax obligations (Figure 4).

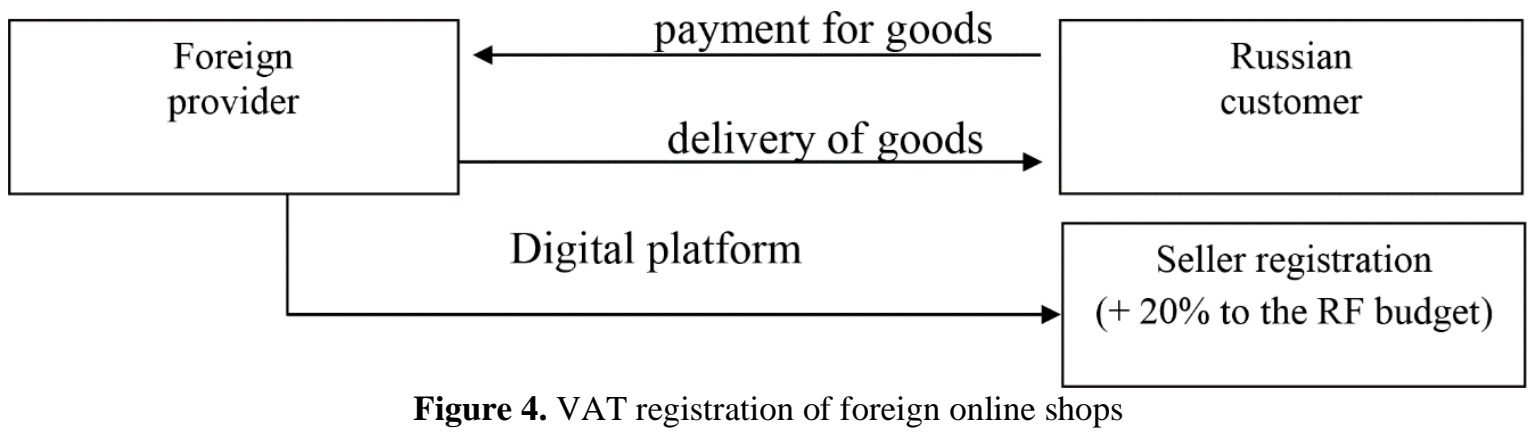

According to the OECD, the application of this regime will improve the efficiency of VAT collection from cross-border online sales because, firstly, this regime will reduce the costs and risks for tax authorities by limiting the number of platforms involved in this regime and, secondly, it will reduce the involvement of jurisdictional customs authorities in the assessment and inspection of "low-value" goods.

2. Partial liability regime. This cross-border e-commerce taxation mechanism does not oblige the platform to perform the jurisdiction's VAT assessment, withholding, payment and declaration obligations on the supplier. Under this regime, jurisdictions may oblige (either routinely or upon request) platforms to share necessary information with tax and customs authorities for tax and customs compliance purposes. For example, a jurisdiction's tax authority may require a platform to provide data on a regular basis on online sales whose value exceeds a value threshold (Orlova et al., 2019).

3. Joint liability regime. This taxation regime offers an obligation to pay VAT on online sales of goods by the supplier to the tax authorities of the jurisdiction. In case of non-compliance by the supplier, the platform will have to take measures to remedy the non-compliance.

\section{Summary}

It is worth noting that, to date, no discussion of such changes is taking place in Russia. However, some European countries (Germany, France, and the UK) have already introduced provisions on the joint liability of digital platforms for tax liabilities in terms of VAT on online sales. The joint and several liability regime introduced in 2016 for foreign sellers and online platforms through which foreign sellers sell goods in the UK implies a number of obligations for the platforms. In 
addition to checking that suppliers' identification number is up to date, and also besides checking their location, tax debts and speed of order fulfilment, the platform is also obliged to exclude unscrupulous suppliers from the platform if they do not have an identification number or otherwise breach UK law. Otherwise, the platform is obliged to pay VAT for such an offender.

\section{Conclusions}

In our opinion, the mechanism proposed by the OECD that would make e-commerce platforms fully responsible for paying VAT on behalf of foreign suppliers would be the most appropriate option for Russia. This taxation mechanism would make it easier for the tax authorities to administer, and would also make it easier for the suppliers themselves, who would not have to register in each tax jurisdiction. For Russia, which is at the beginning of the journey to improve its online trading mechanism, there is a need:

Firstly, to enshrine the concepts of "cross-border e-commerce", "digital platform" and the rights and obligations of participants in cross-border trade in tax legislation;

Secondly, in order to apply the enforcement measures that would be required to compel taxpayers to pay tax, a territorial reference is necessary for a modern tax administration system. It is therefore necessary to enshrine at the statutory level a specific definition for electronic digital representation and to "fix" it as the "place of business" through which the supplier will deliver goods, including the state or territory of digital presence for international e-commerce participants;

Thirdly, in order to monitor possible violations of tax legislation, as well as the tax administration process for cross-border online trade, it is necessary to develop software that allows the tax authorities to accumulate all the information on suppliers, buyers, digital platforms, and orders executed.

It should not be forgotten that Russia has no system of tax administration and control over VAT compliance in relation to import trade. For this reason, it is highly probable that, at their first stage, unscrupulous traders will come up with alternative schemes for importing goods into Russia, and also tax evasion schemes by understating the value of imported goods, and other alternatives.

\section{Acknowledgements}

The work is performed according to the Russian Government Program of Competitive Growth of Kazan Federal University.

\section{References}

"The RF Ministry of Finance has drafted an instruction to EEC to work out a duty-free limit of 20 euros". Interfax. [Electronic resource] URL: https://www.interfax.ru/business/688206. (Access date: 20.05.2020).

Adigamova Farida, F., Safiullin Marat, A., \& Tufetulov Aidar, M. (2014). Mechanism of state tax regulation in the global economy. Mediterranean Journal of Social Sciences, 5(24), 193 199.

Cross-border trade in the Russian Federation or offshore tax-free trade [Electronic resource] URL: https://www.akit.ru/ analitika-akit 2020/. (Access date: 20.05.2020).

Decision of the Council of the Eurasian Economic Commission dated 20 December 2017. N 107 "On certain issues related to goods for personal use". [Electronic resource] URL: http://base.garant.ru/71903282/. (Access date: 20.05.2020).

Kabanov, I. P. (2016). Regulation of duty-free import of goods through international postal items in the world and the EAEU. Russian Foreign Economic Bulletin. no. 9-2016. (Access date: 20.05.2020). P.5-6.

Orlova, M.E, Adigamova, F.F, Nasyrova, V.I. (2019). Tax regulation of the russian economy real sector crediting. International Journal on Emerging Technologies, 10(2), 34-37. 
Tax Code (Part I) of the Russian Federation of July 31, 1998 No. 146-FZ // Collected Legislation of the Russian Federation. - 1998, N 31, art. 3824;

Tax Code (Part II) of August 5, No. 117 - FZ // Collected Legislation of the Russian Federation. 2000, no. 32, art. 3340.

The Role of Digital Platforms in the Collection of VAT/GST on Online Sales, OECD, Paris. [Electronic resource] URL: www.oecd.org/tax/consumption/the-role-of-digital-platformsin-the-collection-of-vat-gst-on-online-sales.pdf. (Access date: 20.05.2020).

Zaponkina A.A. (2020). Cross-border sale of goods on the Internet: problems of taxation and possible solutions. Taxes and Taxation, 2, 52 - 67. 